\title{
Method for testing modern common rail piezoelectric fuel injectors
}

ARTICLE INFO

Received: 15 June 2021

Revised: 15 July 2021

Accepted: 16 July 2021

Available online: 17 July 2021
The paper presents the author's own method for testing piezoelectric common rail fuel injectors, which for many years were consid-ered non-repairable components. This was mainly due to the lack of availability of spare parts and dedicated measuring equipment, enabling full diagnostics under test bench conditions. As a result, their workshop and laboratory servicing was very limited, as effective disassembly concerned basically only the plunger and barrel assembly (needle with nozzle) for selected reference models. The situation has now improved to such an extent that an author's own regeneration procedure has been proposed with the replacement of the most important controls and actuators. The tests were carried out on the example of Siemens $V D O$ Continental PCR 2.3 fuel injectors from one engine, listing the most important stages of this process, including the correction of fuel dosage and returns.

Key words: common rail system, piezoelectric fuel injectors, diagnostic tests, regeneration process

This is an open access article under the CC BY license (http://creativecommons.org/licenses/BY/4.0/)

\section{Introduction}

The main reason for the popularisation of piezoelectric fuel injectors, which gradually replace solutions with a classic electromagnetic coil, is the possibility of multiple division of fuel doses and obtaining very small time intervals between them during one cycle of diesel engine operation [2, 3, 13]. Optimal shaping of the injection process, and thus the preparation of the combustible mixture and the combustion process, allows for the improvement of its dynamic parameters as well as measurable benefits in terms of reducing fuel consumption, exhaust gas toxicity and noise emissions $[11,15,16]$. Meeting these conditions required the introduction of next generations of fuel injectors with a stack of piezoelectric crystals, modified for more flexible control of the multiphase fuel atomisation process and adapted to higher and higher operating pressures $[4,9]$. Unfortunately, the high precision of functional assemblies and individual actuators makes them the most susceptible to damage components of common rail systems in difficult operating conditions $[6,22]$. At the same time, in the absence of support from manufacturers, the possibility of their regeneration was not taken into account in the first years. Over time, for selected catalogue models, a nozzle replacement was introduced, the so-called the first stage of repair, as it was the unit that was damaged most often [10]. However, other spare parts were not offered, mainly valve and piezoelectric actuator assemblies, which effectively limited the scope of service and maintenance procedures. Out of necessity, they came down to external and internal (thermochemical) cleaning, basic electrical measurements, including capacity, resistance, short-circuit to ground [5], as well as diagnostic tests in which the amounts of individual doses and the corresponding fuel overflows were checked. Moreover, selected test benches (e.g. Carbon Zapp CRU2R by Magneti Marelli) made it possible to revitalise the crystal stack, i.e. remove microshort circuits between the layers. However, this process had no effect on the mechanical damage.
The constant development and the increasing participation of piezoelectric fuel injectors being used in modern car engines meant that manufacturers have started to gradually introduce repair technology. For this reason, hardware and dedicated measuring devices have appeared on the market of maintenance services, which allows for the correct verification and assessment of their technical condition, as well as the restoration of factory parameters. The paper presents the author's own regeneration method, which assumes the implementation of such a set goal through two-stage testbench tests, replacement of actuators and key working units, and then changing the control settings.

\section{Methods}

\subsection{Test object}

The tests were carried out on the Siemens VDO Continental 2.3 PCR fuel injectors, the set of which was dismantled from the 2.0 TDCi (Turbo Diesel Common Rail Injection) engine of a Ford C-Max vehicle with an operational mileage of 286 thousand $\mathrm{km}$.

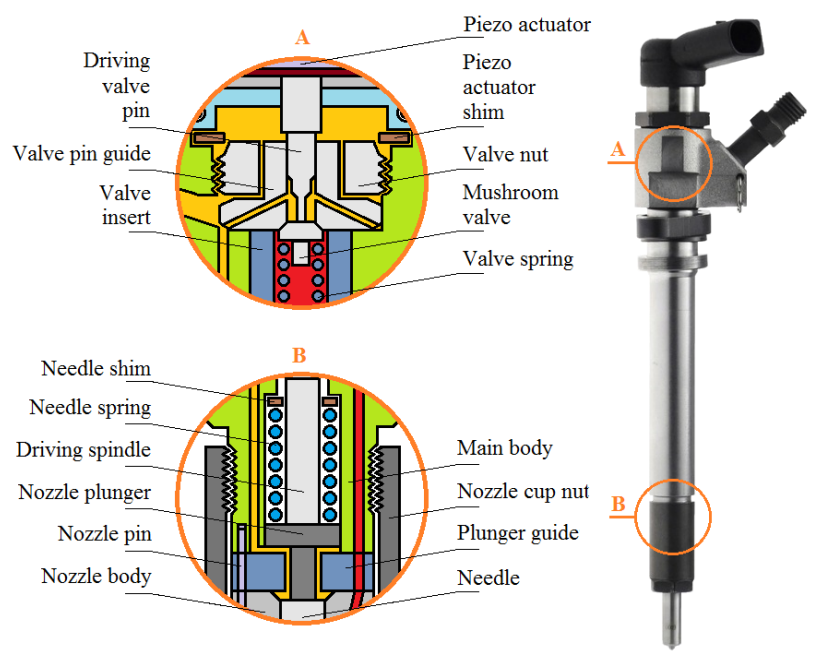

Fig. 1. Siemens VDO Continental PCR 2.3 fuel injector design 
This type of fuel injectors operate at injection pressures not exceeding $160 \mathrm{MPa}$ [20]. A characteristic feature of their construction is the piezoelectric actuator, which is screwed to the upper part of the main body with a nut (Fig. $1)$. As the same assembly occurs in most solenoidcontrolled solutions, with the exception of Delphi products [19], hence the term "coil" has become popular in colloquial speech. It is convenient from the practical side, as it allows for trouble-free replacement of the crystal stack in case of damage and the calibration process.

\subsection{Test beds}

During the regeneration process, the following apparatus and instrumentation were used:

- 12PSB test bench equipped with a Stardex test kit, including the Nova Ultima simulator, Stream flowmeter and Prima cooling, filtering and damping system (Fig. 2),

- Mega Tester V3 piezoelectric actuator tester,

- Yizhan 13MP HDMI VGA industrial microscope camera,

- IP54 electronic micrometer,

- ultrasonic cleaners (Polsonic Sonic 9, Bene YesWeCan 31 ),

- vices, grips and tools for assembling and disassembling fuel injectors.

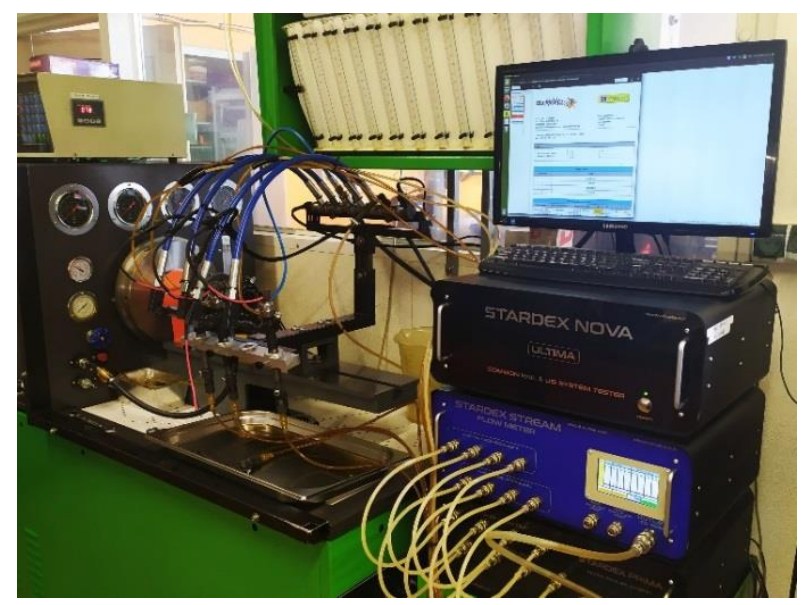

Fig. 2. 12PSB test bench with Stardex kit

\subsection{Research plan}

Figure 3 shows a test plan which only partially overlaps with the procedures specified by Siemens VDO Continental. Thanks to the available equipment, it is possible to detect a piezoelectric actuator failure in the initial phase, which excludes a given fuel injector from thermochemical cleaning and preliminary flow measurements on the test bench. In addition, with the operational mileage over $200,000 \mathrm{~km}$, it is assumed from the top down that the needle and sprayer should be replaced, similarly as is the case with other manufacturers [18]. As a result, visual inspection of the injected fuel stream does not require an additional stage and is performed during test-bench tests. According to the adopted methodology, the microscopic inspection of the plunger and barrel assembly is carried out optionally, primarily in order to detect metallic filings from a faulty pump. Therefore, cleaning in ultrasonic cleaners follows this test and only covers components that will not be replaced. Final acceptance is preceded by the phase of calibration and main tests, repeated when incorrect results of fuel dosing are obtained.

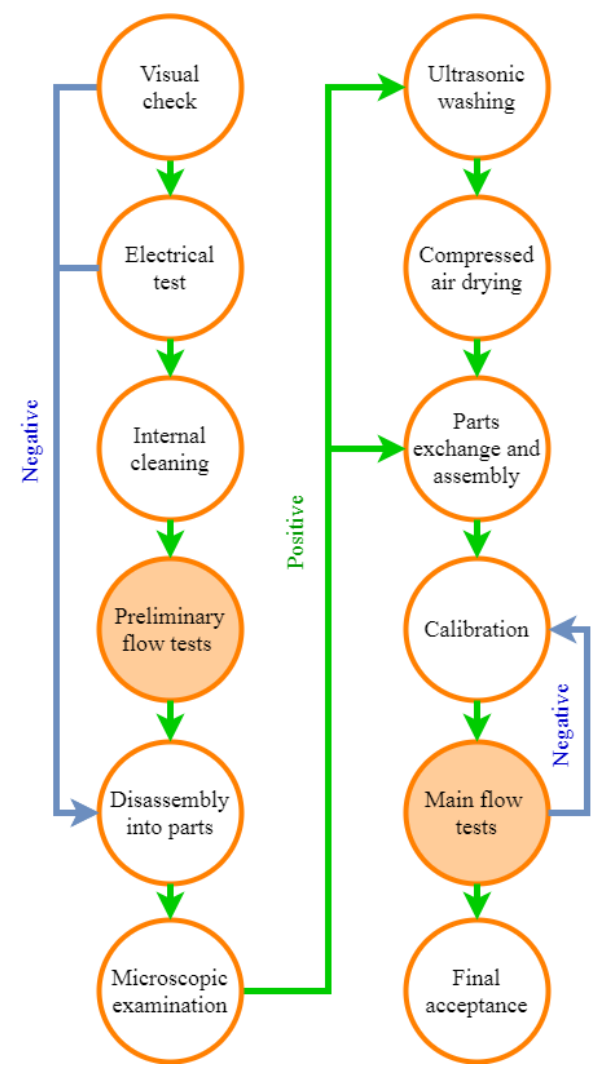

Fig. 3. Research plan

\section{Analysis results and discussion}

\subsection{Preliminary tests}

After the visual inspection, electrical measurements were carried out on the Mega Tester V3 tester. The data presented in Table 1 show that damage to two piezoelectric actuators was detected.

In the fuel injector No. 3, the resistance value was outside the limits recommended by the manufacturer, i.e. 160$220 \mathrm{k} \Omega$ [21]. Moreover, the failure status was signalled on the reading screen with the lightning bolt symbol, which means internal short circuit condition (Fig. 4). In turn, the fuel injector No. 4 was characterised by too low capacity of the crystal stack, which fell below the permissible value of $2.8 \mu \mathrm{F}$, and additionally a negative result was obtained in the continuous load $R_{C}$ test (Fig. 5). As a result, a decision was made to exclude these fuel injectors from the initial flow measurements on the test bench.

When analysing the results of fuel feeding, it can be seen that too low values of the pilot doses were obtained. It proves improper cooperation of the plunger and barrel assemblies, e.g. due to seizure of the needle in the atomiser. In addition, in both cases there was a problem with the valve assembly, which was found after applying very high injection pressures and control times at the Stardex stand. As a result, incorrect dosing value was observed at maximum load (fuel injector No. 1) and for fuel return 1 (fuel 
injector No. 2). The reason could be found in the presence of IDID (Internal Diesel Injector Deposit), which reduce the dynamics of movement of controls and actuators $[1,8,17]$.

Table 1. Results of the preliminary tests

\begin{tabular}{|c|c|c|c|c|c|c|}
\hline \multicolumn{7}{|c|}{ Electric test (Mega Tester 3) } \\
\hline \multicolumn{3}{|c|}{ Type of parameter } & $\begin{array}{c}\text { No. } \\
1\end{array}$ & $\begin{array}{c}\text { No. } \\
2\end{array}$ & $\begin{array}{c}\text { No. } \\
3\end{array}$ & $\begin{array}{c}\text { No. } \\
4\end{array}$ \\
\hline \multicolumn{3}{|c|}{ Piezo actuator resistance, $\mathrm{R}[\mathrm{k} \Omega]$} & 197 & 196 & 82.6 & 199 \\
\hline \multicolumn{3}{|c|}{$\begin{array}{l}\text { Piezo actuator initial capacitance, } \\
\mathrm{C}[\mu \mathrm{F}]\end{array}$} & 3.60 & 3.21 & 3.31 & 2.73 \\
\hline \multicolumn{3}{|c|}{$\begin{array}{l}\text { Continuous resistance test, } \\
\mathrm{R}_{\mathrm{C}}[\mathrm{k} \Omega]\end{array}$} & $\begin{array}{c}195- \\
199\end{array}$ & $\begin{array}{l}194- \\
197\end{array}$ & - & $\begin{array}{l}139- \\
201\end{array}$ \\
\hline \multicolumn{3}{|c|}{$\begin{array}{l}\text { Piezo actuator insulation resistance, } \\
\mathrm{R}_{\mathrm{I}}[\mathrm{M} \Omega]\end{array}$} & $\infty$ & $\infty$ & - & $\infty$ \\
\hline \multicolumn{3}{|c|}{ GAP $[\mu \mathrm{m}]$} & 7.0 & 6.98 & - & 6.5 \\
\hline \multicolumn{7}{|c|}{ Flow measurement results (Stardex Nova Ultima) } \\
\hline \multirow{2}{*}{$\begin{array}{l}\text { Test } \\
\text { name }\end{array}$} & \multirow{2}{*}{$\begin{array}{c}\text { Injection } \\
\text { pressure, } \\
\mathrm{p}_{\text {inj }} \\
{[\mathrm{MPa}]}\end{array}$} & \multirow{2}{*}{$\begin{array}{c}\text { Nozzle } \\
\text { opening } \\
\text { times, } \\
\mathrm{t}[\mu \mathrm{s}]\end{array}$} & \multicolumn{4}{|c|}{$\begin{array}{l}\text { Injection dosage, } \\
\mathrm{d}[\mathrm{ml} / \mathrm{min}]\end{array}$} \\
\hline & & & $\begin{array}{c}\text { No. } \\
1\end{array}$ & $\begin{array}{c}\text { No. } \\
2\end{array}$ & $\begin{array}{c}\text { No. } \\
3\end{array}$ & $\begin{array}{c}\text { No. } \\
4\end{array}$ \\
\hline \multirow{2}{*}{$\begin{array}{l}\text { Back } \\
\text { Flow } 1\end{array}$} & \multirow{2}{*}{135} & \multirow{2}{*}{810} & \multicolumn{4}{|c|}{$[38.0 \pm 26.6]$} \\
\hline & & & 13.8 & 9.6 & - & - \\
\hline \multirow{2}{*}{$\begin{array}{l}\text { Back } \\
\text { Flow } 2\end{array}$} & \multirow{2}{*}{25} & \multirow{2}{*}{540} & \multicolumn{4}{|c|}{$[5.0 \pm 3.0]$} \\
\hline & & & 2.9 & 2.8 & - & - \\
\hline \multirow{2}{*}{$\begin{array}{l}\text { Max } \\
\text { Load }\end{array}$} & \multirow{2}{*}{160} & \multirow{2}{*}{1200} & \multicolumn{4}{|c|}{$[66.8 \pm 10.0]$} \\
\hline & & & 45.7 & 57.6 & - & - \\
\hline \multirow{2}{*}{$\begin{array}{l}\text { Part } \\
\text { Load }\end{array}$} & \multirow{2}{*}{120} & \multirow{2}{*}{600} & \multicolumn{4}{|c|}{$[30.5 \pm 9.2]$} \\
\hline & & & 23.5 & 28.6 & - & - \\
\hline \multirow{2}{*}{$\begin{array}{l}\text { Pre- } \\
\text { injection }\end{array}$} & \multirow{2}{*}{80} & \multirow{2}{*}{180} & \multicolumn{4}{|c|}{$[2.5 \pm 2.1]$} \\
\hline & & & 0.1 & 0.3 & - & - \\
\hline \multirow{2}{*}{ Idle } & \multirow{2}{*}{25} & \multirow{2}{*}{540} & & {$[4$.} & & \\
\hline & & & 5.0 & 4.8 & - & - \\
\hline
\end{tabular}
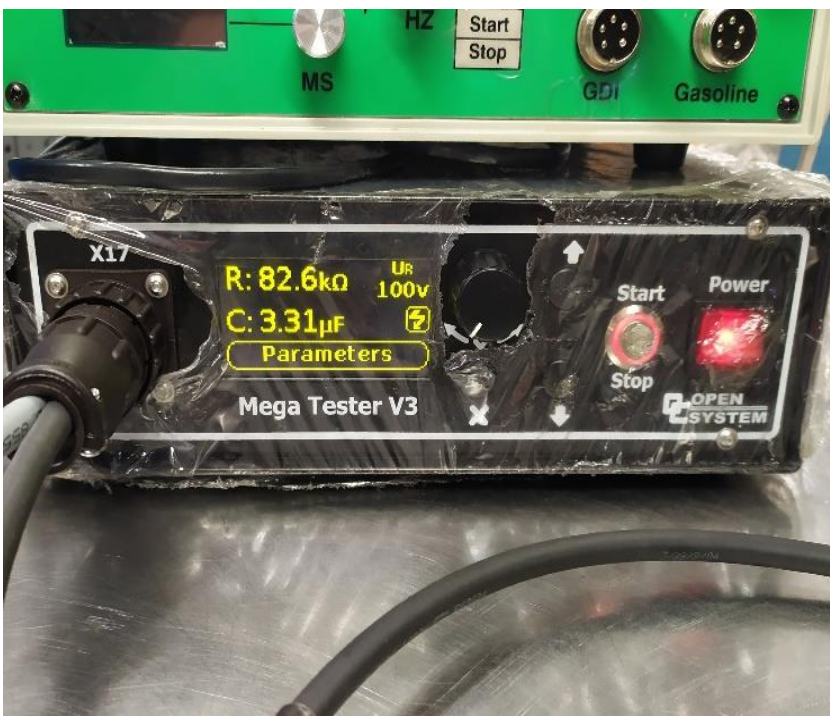

Fig. 4. Failure of the piezoelectric actuator (fuel injector No. 3)

However, it would be premature to make a conclusion about the presence of persistent pollutants, as the fuel injectors underwent a half-hour thermochemical cleaning procedure. It is carried out at a high temperature of detergent in order to dissolve and flush existing deposits. Besides, damage to the valve assembly is affected by various factors, such as destructive erosion and cavitation processes within the valve seat [7]. Therefore, in accordance with the proposed own methodology, the disassembly phase was carried out (Fig. 6).

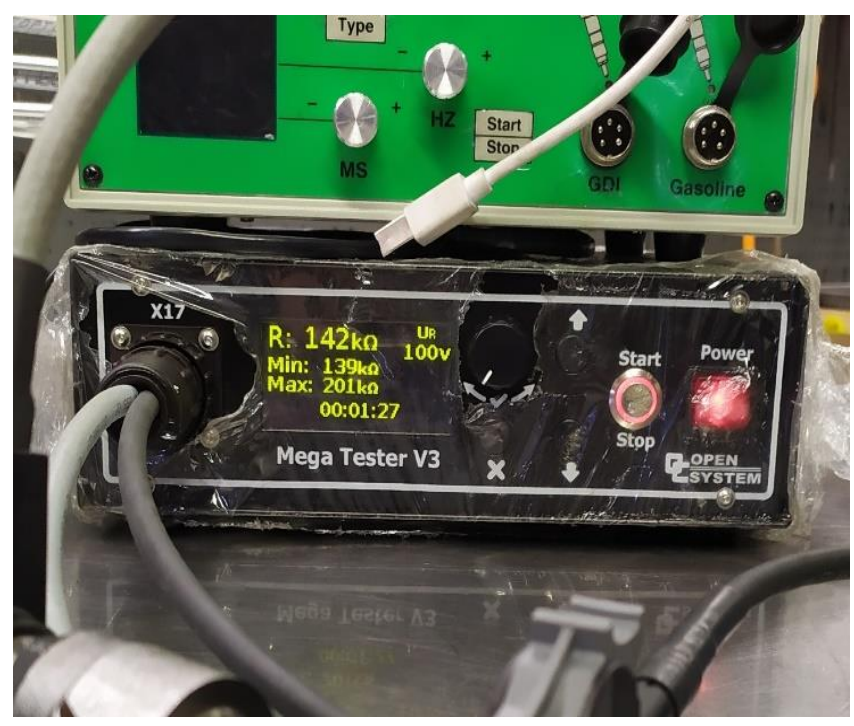

Fig. 5. Negative result of the measurement in the continuous load test

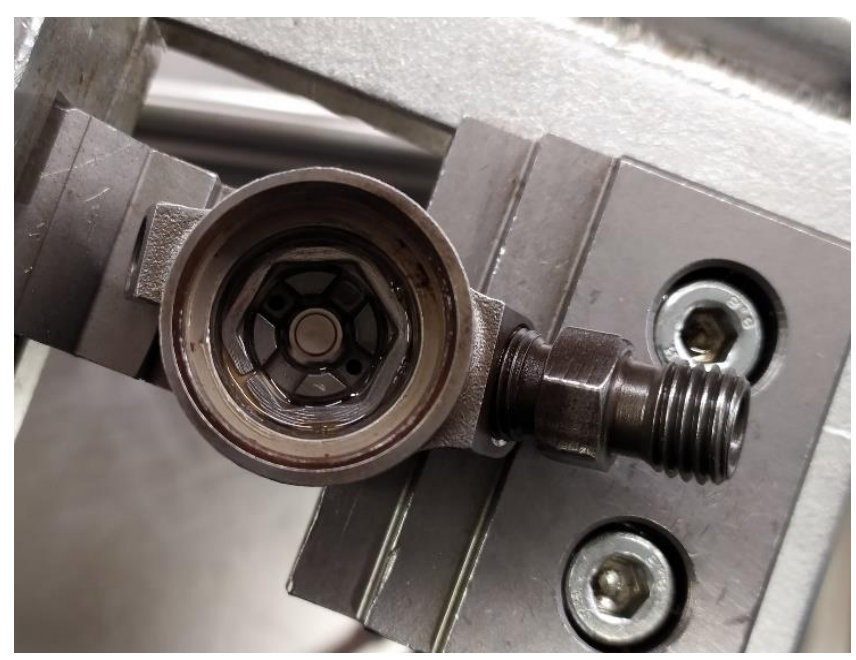

Rys. 6. Fuel injector after disassembling the piezoelectric actuator

The organoleptic examination and high magnification revealed numerous traces of corrosion on the components that had contact with the fuel (Figs 7,8). Due to the frictional wear of the working surfaces, it was decided to replace the sets of nozzles, valve assemblies and drive plungers. New piezoelectric actuators were also used, and the remaining components were bathed in ultrasonic cleaners.

The results of the research presented in the publication [12] indicate that with the temperature increase, the capacity of the crystal stack increases in accordance with the logarithmic dependence. The distance between the actuator and the valve tappet thus compensates for the effect of thermal expansion, but the gap size is additionally affected by the degree of polarisation of the piezoelectric elements. Therefore, the regulation should be performed at room temperature, eliminating the influence of too high or negative stack voltage [14]. Due to the underestimated dosing method in the preliminary test, the GAP parameter was reduced to $4 \mu \mathrm{m}$ in all fuel injectors (Fig. 9). As the maximum tightening torque of the actuator is $20 \pm 5 \mathrm{Nm}$, hence shims from the lower selection group were measured and selected prior to assembly (Fig. 10). 


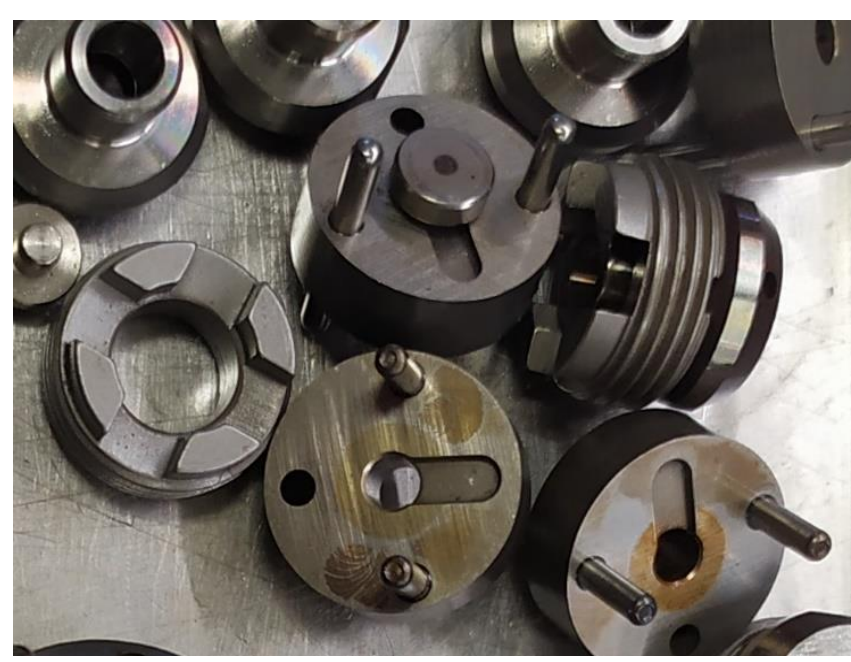

Fig. 7. Disassembled nozzle plunger guides and valve assemblies

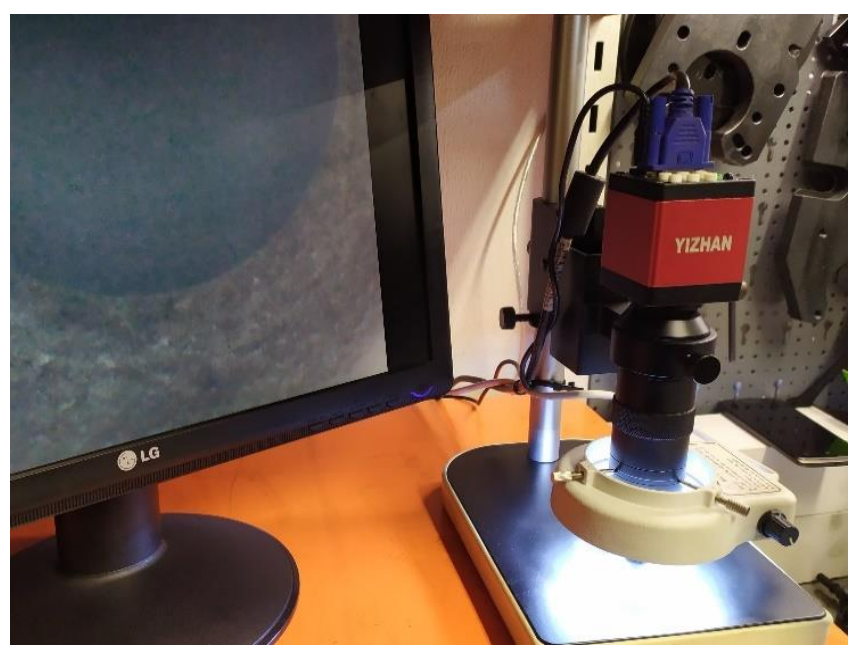

Fig. 8. Examination of the valve seat on a microscope stand

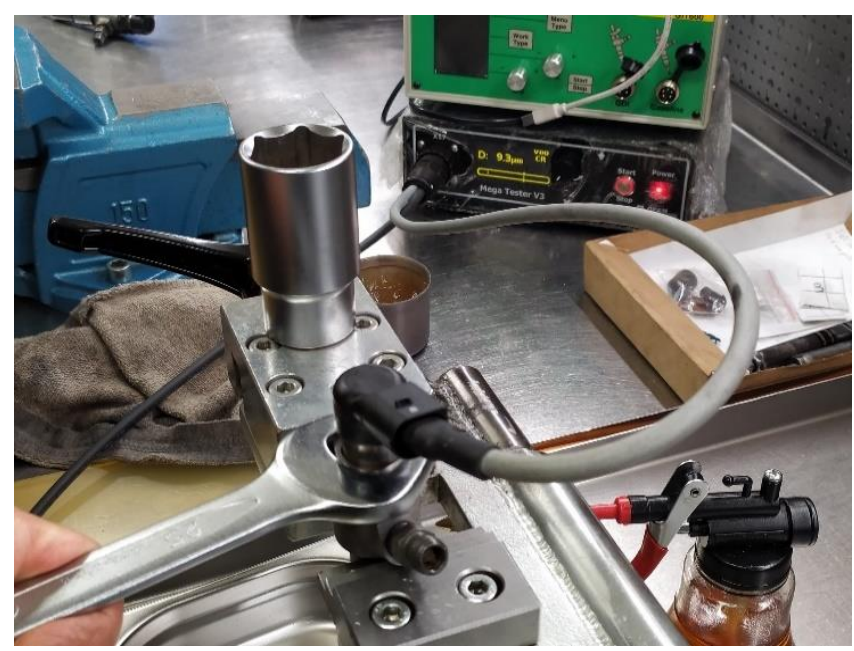

Fig. 9. GAP regulation using the Mega Tester V3 tester

\subsection{Main tests}

Table 2 shows the results of the main tests that were carried out after the completed regeneration process of the tested fuel injectors. It can be seen that the values of fuel doses and overflows are similar to each other, and additionally they fall within the manufacturer's limits. In this re- gard, the method of adjustment, which was carried out during assembly, played a key role. The Mega Tester V3 tester, while sending the test signal, measured the GAP parameter on an ongoing basis, which enabled the assessment of the applied torque. Failure to control this process could result in improper pressure of the crystal stack on the valve plunger and a disturbed response of the mushroom valve opening the borehole that connects the control chamber with the fuel return (Fig. 1).

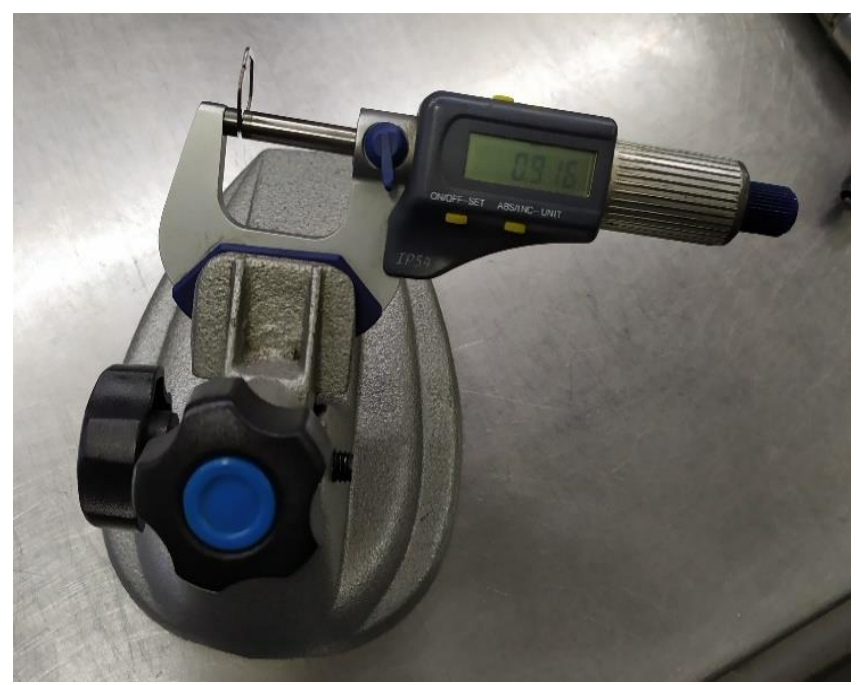

Fig. 10. Measurement of the thickness of the actuator shim

Table 2. Results of the main tests

\begin{tabular}{|c|c|c|c|c|c|c|}
\hline \multicolumn{7}{|c|}{ Electric test (Mega Tester 3) } \\
\hline \multicolumn{3}{|c|}{ Type of parameter } & $\begin{array}{c}\text { No. } \\
1\end{array}$ & $\begin{array}{c}\text { No. } \\
2\end{array}$ & $\begin{array}{c}\text { No. } \\
3\end{array}$ & $\begin{array}{c}\text { No. } \\
4\end{array}$ \\
\hline \multicolumn{3}{|c|}{$\begin{array}{l}\text { Piezo actuator resistance, } \\
\mathrm{R}[\mathrm{k} \Omega]\end{array}$} & 200 & 199 & 200 & 198 \\
\hline \multicolumn{3}{|c|}{$\begin{array}{l}\text { Piezo actuator initial capacitance, } \\
\mathrm{C}[\mu \mathrm{F}]\end{array}$} & 3.65 & 3.61 & 3.64 & 3.62 \\
\hline \multicolumn{3}{|c|}{$\begin{array}{l}\text { Continuous resistance test, } \\
\mathrm{R}_{\mathrm{C}}[\mathrm{k} \Omega]\end{array}$} & $\begin{array}{l}199- \\
201\end{array}$ & $\begin{array}{l}199- \\
202\end{array}$ & $\begin{array}{l}198- \\
201\end{array}$ & $\begin{array}{l}197- \\
200\end{array}$ \\
\hline \multicolumn{3}{|c|}{$\begin{array}{l}\text { Piezo actuator insulation resistance, } \\
\mathrm{R}_{\mathrm{I}}[\mathrm{M} \Omega]\end{array}$} & \multicolumn{4}{|c|}{$\infty$} \\
\hline \multicolumn{3}{|c|}{ GAP $[\mu \mathrm{m}]$} & \multicolumn{4}{|c|}{4,0} \\
\hline \multicolumn{7}{|c|}{ Flow measurement results (Stardex Nova Ultima) } \\
\hline \multirow{2}{*}{$\begin{array}{l}\text { Test } \\
\text { name }\end{array}$} & \multirow{2}{*}{$\begin{array}{c}\text { Injection } \\
\text { pressure, } \\
\mathrm{p}_{\text {inj }} \\
{[\mathrm{MPa}]}\end{array}$} & \multirow{2}{*}{$\begin{array}{c}\text { Nozzle } \\
\text { opening } \\
\text { times, } \\
\mathrm{t}[\mu \mathrm{s}]\end{array}$} & \multicolumn{4}{|c|}{$\begin{array}{c}\text { Injection dosage, } \\
\mathrm{d}[\mathrm{ml} / \mathrm{min}]\end{array}$} \\
\hline & & & $\begin{array}{c}\text { No. } \\
1\end{array}$ & $\begin{array}{c}\text { No. } \\
2\end{array}$ & $\begin{array}{c}\text { No. } \\
3\end{array}$ & $\begin{array}{c}\text { No. } \\
4\end{array}$ \\
\hline \multirow{2}{*}{$\begin{array}{l}\text { Back } \\
\text { Flow } 1\end{array}$} & \multirow{2}{*}{135} & \multirow{2}{*}{810} & \multicolumn{4}{|c|}{$[38.0 \pm 26.6]$} \\
\hline & & & 16.7 & 16.0 & 16.1 & 16.4 \\
\hline \multirow{2}{*}{$\begin{array}{l}\text { Back } \\
\text { Flow } 2\end{array}$} & \multirow{2}{*}{25} & \multirow{2}{*}{540} & \multicolumn{4}{|c|}{$[5.0 \pm 3.0]$} \\
\hline & & & 3.7 & 3.3 & 3.9 & 3.2 \\
\hline \multirow{2}{*}{$\begin{array}{l}\text { Max. } \\
\text { Load }\end{array}$} & \multirow{2}{*}{160} & \multirow{2}{*}{1200} & \multicolumn{4}{|c|}{$[66.8 \pm 10.0]$} \\
\hline & & & 64.6 & 65.0 & 66.1 & 64.8 \\
\hline \multirow{2}{*}{$\begin{array}{l}\text { Part } \\
\text { Load }\end{array}$} & \multirow{2}{*}{120} & \multirow{2}{*}{600} & \multicolumn{4}{|c|}{$[30.5 \pm 9.2]$} \\
\hline & & & 31.5 & 31.7 & 32.1 & 31.6 \\
\hline \multirow{2}{*}{$\begin{array}{l}\text { Pre- } \\
\text { injection }\end{array}$} & \multirow{2}{*}{80} & \multirow{2}{*}{180} & \multicolumn{4}{|c|}{$[2.5 \pm 2.1]$} \\
\hline & & & 1.7 & 1.6 & 1.8 & 1.6 \\
\hline \multirow{2}{*}{ Idle } & 25 & 540 & & & $.5]$ & \\
\hline & 25 & 540 & 5.7 & 5.4 & 5.8 & 5.5 \\
\hline
\end{tabular}

On the other hand, if the nut was tightened too weakly to the upper part of the body, the fuel injector could become unsealed. The functionality of the device allows not only to assess the degree of damage to the piezoelectric actuator itself, as demonstrated in preliminary tests, but also ensures 
its proper assembly and calibration in the final stages. Due to the above considerations, more and more testers of similar purpose (e.g. CRI250, CRistina-Piezo, DiGiMaster) are offered on the maintenance services market, and their use facilitates the repair of fuel injectors from other manufacturers.

\section{Conclusions}

The proposed method allows for full diagnostics of piezoelectric common rail fuel injectors, as shown in the example. Due to the extended scope of maintenance procedures, the regeneration process is analogous to the solutions with a traditional electromagnetic coil, despite a completely different structure and working principle. The most important advantages and possibilities of tests conducted in this way include:

- comprehensive inspection of the electrical part, including measurement under continuous load and establishing the value of the gap between the crystal stack and the valve tappet,

- shortening the time-consuming procedure by excluding fuel injectors with a faulty actuator from internal cleaning and preliminary tests,
- elimination of a separate stage of visual assessment of the supplied fuel stream, which is carried out during measurements on the test bench,

- complete disassembly of the fuel injector, without the need to mark the position of the piezoelectric actuator in relation to the main body,

- optional microscopic inspection of the needle with an atomiser, performed only in the case of detection of filings from an inoperative pump on other components,

- ultrasonic cleaning of only those components that will not be replaced with new ones,

- replacement of the most important actuators and controls, impossible to carry out in the previously used stages of repair,

- ongoing control of the torque applied to the piezoelectric actuator nut during the calibration process.

\section{Acknowledgements}

The paper was created thanks to the cooperation with AUTO NEXT SERWIS service company based in Szczecin (Prawobrzeże Quarter), which provided test benches, apparatus and accessories used in the regeneration process of the tested fuel injectors.

\section{Nomenclature}

C piezo actuator initial capacitance

d injection dosage

GAP space between the piezo actuator and the injector hydraulic valve pusher

IDID Internal Diesel Injector Deposit

PCR Piezo Common Rail $\mathrm{p}_{\mathrm{inj}} \quad$ injection pressure

$\mathrm{R} \quad$ piezo actuator resistance

$R_{C} \quad$ continuous resistance test

$\mathrm{R}_{\mathrm{I}} \quad$ piezo actuator insulation resistance

$\mathrm{t} \quad$ nozzle opening times

TDCi Turbo Diesel Common Rail Injection

\section{Bibliography}

[1] CORBETT, P.J., MCINTOSH, A.J.S., GEE, M. et al. Use of ionic liquids to minimize sodium induced internal diesel injector deposits (IDIDs). Molecular Systems Design \& Engineering. 2018, 3, 397-407.

https://doi.org/10.1039/C7ME00110J

[2] CHOMIK, Z., ŁAGOWSKI, P. The analysis of mechanical damage of Common Rail injectors. Journal of Research and Applications in Agricultural Engineering. 2019, 64(1), 1320.

[3] CZAJKA, J., PIELECHA, I., WISŁOCKI, K. A comparative analysis of diesel fuel injection parameters in piezoelectric and electromagnetic fuel injectors. Combustion Engines. 2009, 138(3), 54-63. https://doi.org/10.19206/CE-117177

[4] EGGER, K., WARGA, J., KLÜGL, W. New common rail injection system with piezo actuation for diesel passenger cars. MTZ worldwide. 2002, 63(9), 14-17.

[5] GÜNTHER, H. Common-Rail-Systeme in der Werkstattpraxis. Technik, Prüfung, Diagnose, $4^{\text {th }}$ ed., Krafthand Verlag Walter Schultz GmbH. 2012, Bad Wörihofen.

[6] IDZIOR, M., BOROWCZYK T., KARPIUK, W. et al. Możliwości badania stanu technicznego nowoczesnych wtryskiwaczy silników o zapłonie samoczynnym. Logistyka. 2011, 3, 933-942.

[7] IGNACIUK, P., GIL, L. Damages to injectors in diesel engines. Advances in Science and Technology Research Journal. 2014, 21(8), 58-61.

https://doi.org/10.12913/22998624.1091880
[8] JAKÓBIEC, J., WADRZYK, M., CIEŚLIKOWSKI, B. et al. The process of deposit formation on piezoelectric injector of common rail fuel injection system. Journal of Research and Applications in Agricultural Engineering. 2017, 62(1), 48-54.

[9] KACZOROWSKI, M., PILEWSKI, Z. Wtryskiwacze piezoelektryczne - pionierzy wysokich ciśnień do 2500 barów. Bosch Autospec. 2017, 65(3), 7-10.

[10] KONIECZNY, Ł., ADAMCZYK, B., ADAMCZYK, G. Diagnostyka i regeneracja wtryskiwaczy CR. Zeszyty Naukowe Politechniki Śląskiej. Seria: Transport, 2015, 86, 6573.

[11] KÖTEN, H., GUNES, E.C., GUNER, K. Piezo-actuated common rail injector structure and efficient design. Journal of Energy Systems. 2018, 2(1), 97-114. https://doi.org/10.30521/jes.453560

[12] KRIVTSOV, S.N., KRIVTSOVA, T.I. Variations in health of piezoelectric elements of the Common Rail electric hydraulic nozzles in the operating conditions. IOP Conference Series: Materials Science and Engineering. 2021, 1061, 1-8. https://doi.org/10.1088/1757-899X/1061/1/012022

[13] LEE, Y., LEE, C.H. Development of diesel piezo injector driver using microcontrollers. ARPN Journal of Engineering and Applied Sciences. 2018, 13(18), 4860-4865.

[14] MEGA TESTER V3. Software instruction manual version 3.0. The private company "Open System". 2019, Khmelnitsky. 
[15] SATKOSKI, C.A., SHAVER, G.M., MORE, R. et al. Dynamic modeling of a piezoelectric actuated fuel injector. Proceedings of the 2009 IFAC Workshop on Engine and Powertrain Control, Simulation and Modeling IFP. 2009, 235-240. http://doi.org/10.3182/20091130-3-FR-4008.0048

[16] SHASHANK, M. Piezoelectric diesel injectors \& emission control. International Journal of Science and Research. 2015, 4(1), 1-3.

[17] STĘPIEN, Z. A study of factors influencing the formation of harmful deposits in the diesel engine injectors. Eksploatacja i Niezawodność - Maintenance and Reliability. 2017, 19(3), 331-337. http://dx.doi.org/10.17531/ein.2017.3.3

[18] STOECK, T. Application of the experimental design technique in fuel dose adjustment of common rail injector. Combustion Engines. 2019, 179(4), 210-215. https://doi.org/10.19206/CE-2019-435

Tomasz Stoeck, DEng. - Department of Automotive Engineering, West Pomeranian University of Technology in Szczecin, Poland.

e-mail: tstoeck@wp.pl
[19] STOECK, T. Methodology of testing common rail fuel injectors witch the use of Gauss`s formulas. Combustion Engines. 2021, 184(1), 11-15. https://doi.org/10.19206/CE-133505

[20] URBAN, J. Study of the car fifth TDI-PCR-2L diesel engine with selective catalytic reduction medial load. Journal of KONES Internal Combustion Engines. 2005, 12, 3-4.

[21] VDO. CR injector test and Repair. Manual Version 1.21. Continental Trading GmbH, 2014, Schwalbach.

[22] ZAJĄC, G., KACZOR, G. Analiza niezawodności wtryskiwaczy. Technical Transactions. Mechanics, Czasopismo Techniczne. Mechanika. 2012, 14(7-M), 327-334.

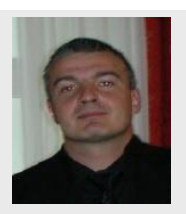

